\title{
Microwave ablation versus Radiofrequency ablation in the management of Hepatocellular carcinoma
}

\author{
Hasan S. Mahmoud ${ }^{a}$, Shimaa Arafat ${ }^{a}$, Saad Zaky ${ }^{b}$, Shamardan Ezzeldin S. Bazeed ${ }^{a}$ \\ ${ }^{a}$ Tropical Medicine and Gastroenterology Department, Faculty of Medicine, South ValleyUniversity, \\ Qena, Egypt. \\ b Tropical Medicine and Gastroenterology Department, Faculty of Medicine, Assiut University, Assiut, \\ Egypt.
}

Background: Different loco-regional therapies have been progressed for irresectable liver tumors to achieve local tumor control. Examples of loco-regional therapies are different thermal ablation therapies such as microwave ablation, and radiofrequency ablation.

Objectives: We aimed to evaluate treatment safety, efficacy, and complications related to radio-frequency ablation (RFA) in comparison with percutaneous microwave (MW) ablation for the management of HCC. Patients and Methods: 100 patients presented with liver cirrhosis and HCC proved by imaging ultrasonography and triphasic CT. Patients were assigned into two main comparison groups:

Group 1: patients with single or multiple hepatic focal lesions (size up to $4 \mathrm{~cm}$ ) who received RFA. Group 2: patients with single or multiple hepatic focal lesions (size up to $4 \mathrm{~cm}$ ) who received MWA. Complete blood count, liver function tests, and AFP were measured for all subjects.

Results: In All 100 patients; the assessment number of the hepatic focal lesion was done by abdominal ultrasonography and triphasic CT $93 \%$ of patients had a single focal lesion with a median size of $2.3 \mathrm{~cm}$. Group (1): (who were candidates for RFA) showed statistically significant higher values as regard (ALT) ( $p$-value $=0.091$ ) compared to group (2): (who were candidates for MWA).

There were no statistical differences between both groups as regard Total Bilirubin and serum AFP. The microwave ablation group was statistically significant as regard ablation success, shorter time, and shorter ablation than the radiofrequency ablation group ( $\mathrm{p}$-value $=0.000$ ).

Conclusions: RFA and MWA are good ablative techniques. MWA showed more superiority than RFA in the overall outcome.

Keywords: Radiofrequency ablation; Microwave ablation; Hepatocellular carcinoma; AFP and hepatic focal lesion.

\section{Introduction}

The fifth most common cancer in the world is Hepatocellular carcinoma (HCC) $(564,000$ cases per year) and the third cause of cancerrelated deaths (Luo et al., 2005). Surgical resection is a curative therapy. Although, only about $20 \%$ of HCC patients are resectable; the remainders are irresectable due to multifocal tumors, advanced tumors, tumor location precluding complete resection, or poor hepatic functional reserve (Solmi et al., 2006). Treatment options are restricted in most patients with HCC by the liver dysfunction caused by chronic liver disease and cirrhosis. offers the best chance of long-term survival, cirrhosis may limit the amount of parenchymal resection that will be tolerated and increases the risk of postoperative liver failure and death (Starzl, 2000; Fan et al., 1999; Nagasue, 1998). Systemic or regional chemotherapy is the best palliative in a small number of patients but chemotherapy has many side effects and reduced quality of life (Mazziotti et al., 1998). In this estimation, local ablation therapy is the best option due to it does not need surgical interference in a living person, and it improves the quality of life for the patient and the health. However, resection and liver transplantation estimate more than 50\% Five-year disease-free survival (Liu et al., 2004; Steven et al., 2000).

Copyright: (c) Mahmoud et al. (2021) Immediate open access to its content on the principle that making research freely available to the public supports a greater global er RFA or exchange of knowledge. Users have the right to Read, download, copy, distribute, print or share link to the full texts under a Creative Commons BY-NC-SA 4.0 
MWA, is considered the best loco-regional treatment choice for unresectable hepatic focal lesion of early stage, but its use has been proposed for the decrease of the tumor burden and as a bridge to transplantation (Molla et al., 2014; Francis et al., 2005). We aimed to evaluate treatment safety, efficacy, and complications related to radio-frequency ablation (RFA) in comparison to percutaneous microwave (MW) ablation for the management of HCC.

\section{Patients and Methods:}

Patients: This Prospective Open-label study Cohort study includes patients who presented with liver cirrhosis and proved with HCC in inpatient of Tropical Medicine and Gastroenterology department; Qena Faculty of medicine from October 2017 to November 2020.

Inclusion criteria: Patients proved to have HCC in Qena university hospital enrolled after signing informed consent. Patients were assigned into two main comparison groups:

Group 1: patients with single or multiple hepatic focal lesions (size up to $4 \mathrm{~cm}$ ) who received RFA ablation therapy.

Group 2: patients with single or multiple hepatic focal lesions (size up to $4 \mathrm{~cm}$ ) who received MWA ablation therapy.

\section{b. Exclusion criteria:}

1. Patients who refused to be enrolled in the study.

2. Platelet count was less than $40,000 / \mathrm{mL}$.

3. Prothrombin time more than 1.5 times above normal.

4. The presence of metallic devices such as pacemakers was excluded from RFA ablation. Follow up after one month and 3 months of procedure in first 6 months, by using a CT or MRI scan of the abdomen, and the same serum laboratory tests were done. Based on the clinical history, physical examination, and serum laboratory findings, the clinical severity of the patient's cirrhosis scored using the ChildTurcotte-Pugh system.

\section{Methodology:}

Participants were subjected to the following:

Laboratory investigations: $\mathrm{CBC}$, ESR, CRP, AFP, liver function tests; ALT and AST. Hepatitis B and C virus serology was detected by an enzyme immunoassay (EIA) Cobas e411 (Roche Diagnostic Mannheim Germany).
$5 \mathrm{~mL}$ of venous blood was collected in a $\mathrm{BD}$ Vacutainer®) EDTA, ESR tube, and plain tube that was kept upright at room temperature for $30 \mathrm{~min}$ to allow for clotting. They were then spun in a centrifuge at $25^{\circ} \mathrm{C}$ and $3000 \mathrm{RPM}$ for 10 minutes. The serum used for CRP Nephlometric quantitative assay (Roche Cobas C311) (Roche Diagnostics, Mannheim, Germany). All assays were performed by employing the Standard Operating Procedure (SOP), and as indicated by the manufacturer's instructions.

Imaging study: Both abdominal ultrasound and triphasic abdominal and pelvic CT were done for all included patients as diagnostic tools and evaluation of hepatic focal lesion.

Studied groups: including

Group 1: HCC patients with single or multiple focal lesions (size up to $4 \mathrm{~cm}$ ) who received RFA ablation therapy. Group 2: HCC patients with single or multiple focal lesions (size up to $4 \mathrm{~cm}$ ) were received MWA ablation therapy.

\section{Statistical analysis}

In the current study, the statistical analysis was done using the Statistical Package for Social Sciences (SPSS) version 20 software for Windows (IBM Corporation, Armonk, NY, USA). The data was firstly tested for confirming normality using the KolmogorovSmirnov test and for confirming homogeneity variances before starting the analysis. Symmetrically distributed continuous variables were presented as mean and standard deviation (mean, SD). But the skewed variables presented as median and range (IQR) and categorical variables presented as number (NO) and percentage (\%). We used the Mann- Whitney U-Test for the quantitative data, Kruskal-Wallis test for nonhomogeneous and not normally distributed variables, and the independent student-t-test for homogenous normal distributed variables. All calculation was tow-tailed tested, and the $\mathrm{P}$-value $<0.5$ was considered significant.

Ethical approval: The protocol of the study was firstly approved by our institutional ethical committee. Patients provided informed consent before their recruitment.

Results: 100 patients were included in the current study with their mean ages were 
$48.1 \pm 10.4 ; 62(62 \%)$ were males. (49\%) of patients were symptomatic patients with no hepatomegaly or ascites. (Table 1)

Laboratory investigation: Total bilirubin was less than $1.5 \mathrm{mg} / \mathrm{dl}$ in 67 patients, serum ALT less than $100 \mathrm{IU} / \mathrm{L}$ in 86 patients. Evaluation of serum AFP showed that there were only 8 patients had an elevation in serum AFP more than or equal to $400 \mathrm{ng} / \mathrm{ml}$. The ChildTurcotte-Pugh class at the time of evaluation patients before RFA and MVA ablation were $85 \%$ of patients child (A), while $(15 \%)$ of patients were a child (B). (Table 2)

Imaging data for assessment hepatic focal lesion: Assessment number of the hepatic focal lesion was done by abdominal ultrasonography and triphasic CT 93\% had single focal lesion with median size $2.3 \mathrm{~cm}$ range (1.7-4) (Table 1).

Comparisons between both groups

Baseline characteristics data between both groups: There was no statistically significant difference as regard age, gender, and etiology of liver cirrhosis.

Laboratory investigation between both groups: Group (1) showed higher statistically significant values as regard lab investigations (ALT) $(\mathrm{p}$ value $=0.091)$ compared to group (2). There was no statistically difference between both groups as regard Total Bilirubin and serum AFP (Table 2).

Sonographic imaging of hepatic focal lesion between both groups: There was no statistically significant difference between both groups as regard number, size, and site of hepatic focal lesion (Table 2).

The Success and recurrence in patients with RFA (group 1) were illustrated in (table 3). Local recurrences developed in eight patients $(16 \%)$ tumors more than $3.0 \mathrm{~cm}$ in diameter. All local recurrences were appeared about 6 months after RFA.

There was no statistically significant difference in the age, sex, number of focal lesions, or segment of affected hepatic lobe distribution of patients who had complete ablation versus recurrence apart from the size of the focal lesion is highly statistically significant $(p$-value $=0.000)$.
The Success and recurrence in patients with MVA (group 2) were illustrated in (table 4). Two patients $(4 \%)$ had local recurrence with the diameter of about more than $3.0 \mathrm{~cm}$. All local recurrences were evident within 6 months after MWA.

There was no statistical significant difference in the age, sex, size of the focal lesion, number of focal lesions, or segment of affected hepatic lobe distribution of patients who had complete ablation versus recurrence.

Comparisons between two groups according to Success and recurrence were illustrated in (table 5). Two groups were evaluated for success ablation, recurrence of focal lesion, and time of ablation. Microwave ablation group had a significant improvement. Operation time was significantly shorter in the microwave ablation group ( $\mathrm{p}$-value $=0.000$ ). Complications related to RFA developed in 8 patients $(16 \%)$, were illustrated in (table 6). Two patients had sub-capsular and two patients have sub-cutaneous hematoma which was associated with local pain for 1 week after percutaneous RFA, but they not required blood transfusion, and symptoms resolved within 1 week. While four patients had right-sided pleural effusion developed within two weeks after RFA. We treated them by diuretics. Complications related to MVA developed in 2 patients (4\%), were illustrated in (Table 7). Two patients has sub-cutaneous hematoma were noted but not needed a blood transfusion, and symptoms improved within 10 days. Difference between RFA, MVA ablation complications: These two groups showed statistically significantly higher values as regard postoperative complication $(\mathrm{p}$ value $=$ 0.000) (Table 8).

Table 1: Baseline characteristics of patients with HCC

\begin{tabular}{|l|l|c|}
\hline Variable & Categories & $\begin{array}{c}\text { Patient } \\
\text { s' data } \\
(\mathbf{n = 1 0 0})\end{array}$ \\
\hline Age & Years & $48.1 \pm$ \\
& & 10.4 \\
\hline Sex & $\bullet$ Male & 62 \\
& $\bullet$ Female & $(62.0)$ \\
& & 38 \\
& & $(38.0)$ \\
\hline Cause of & $\bullet \mathrm{HCV}$ & 67 \\
\hline
\end{tabular}




\begin{tabular}{|c|c|c|}
\hline cirrhosis & $\begin{array}{ll}\text { - } & \mathrm{HBV} \\
\text { - } & \mathrm{HCV}-\mathrm{HBV} \\
\text { - } & \text { Unknown }\end{array}$ & $\begin{array}{c}(67.0) \\
23 \\
(23.0) \\
6(6.0) \\
4(4.0)\end{array}$ \\
\hline $\begin{array}{l}\text { Clinical } \\
\text { examination }\end{array}$ & $\begin{array}{l}\text { - Clinical free } \\
\text { - Hepatomega } \\
\text { ly } \\
\text { - Ascites }\end{array}$ & $\begin{array}{c}49 \\
(49.0) \\
29 \\
(29.0) \\
22 \\
(22.0)\end{array}$ \\
\hline Child score & $\begin{array}{ll}\text { - } & \mathrm{A} \\
\text { - } & \mathrm{B}\end{array}$ & $\begin{array}{c}85 \\
(85.0) \\
15 \\
(15.0)\end{array}$ \\
\hline $\begin{array}{l}\text { Total } \\
\text { bilirubin }\end{array}$ & $\begin{array}{ll}- & <1.5 \mathrm{mg} / \mathrm{dL} \\
-\quad & \geq 1.5 \mathrm{mg} / \mathrm{Dl}\end{array}$ & $\begin{array}{c}67 \\
(67.0) \\
33 \\
(33.0) \\
\end{array}$ \\
\hline INR & & $\begin{array}{c}1.194 \pm \\
0.175\end{array}$ \\
\hline Serum AFP & 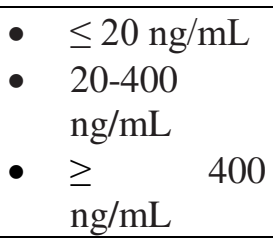 & $\begin{array}{c}52 \\
(52.0) \\
40 \\
(40.0) \\
8(8.0)\end{array}$ \\
\hline Serum ALT & $\begin{array}{l}\text { - } \quad \leq 100 \mathrm{IU} / \mathrm{L} \\
\text { - } \quad>100 \mathrm{IU} / \mathrm{L}\end{array}$ & $\begin{array}{c}86(86.0 \\
) \\
14(14.0 \\
)\end{array}$ \\
\hline $\begin{array}{l}\text { Number of } \\
\text { focal lesion }\end{array}$ & $\begin{array}{ll}-1 \\
\text { - } & 2\end{array}$ & $\begin{array}{c}93 \\
(93.0) \\
7 \quad(7.0)\end{array}$ \\
\hline $\begin{array}{l}\text { Size of focal } \\
\text { lesion }\end{array}$ & $2.3(1.7-4)$ & 3 \\
\hline
\end{tabular}

Data are expressed as Mean \pm Standard deviation OR number (\%) as appropriate. $n=$ number

Table 2: Baseline characteristics comparison between patients before RFA \& MVA

\begin{tabular}{|l|ll|l|}
\hline \multicolumn{1}{|c|}{ Variable } & \multicolumn{1}{|c|}{ Categories } & $\begin{array}{c}\text { P- } \\
\text { value }\end{array}$ \\
\hline Age & Years & 0.916 \\
\hline Sex & $\bullet$ & Male & 0.537 \\
\hline $\begin{array}{l}\text { Cause of } \\
\text { cirrhosis }\end{array}$ & $\bullet$ & HCV & \\
& $\bullet$ & $\mathrm{HBV}$ & 0.362 \\
\hline $\begin{array}{l}\text { Total } \\
\text { bilirubin }\end{array}$ & $\bullet$ & $\mathrm{H}$ Unknown & \\
\hline Serum AFP & $\bullet$ & $\leq 1.5 \mathrm{mg} / \mathrm{dL}$ & 0.362 \\
\hline
\end{tabular}

\begin{tabular}{|l|l|l|}
\hline & $\begin{array}{l}\bullet 20-400 \mathrm{ng} / \mathrm{mL} \\
\bullet \geq 400 \mathrm{ng} / \mathrm{mL}\end{array}$ & \\
\hline Serum ALT & $\begin{array}{l}\bullet \leq 100 \mathrm{IU} / \mathrm{L} \\
\bullet \quad>100 \mathrm{IU} / \mathrm{L}\end{array}$ & 0.745 \\
\hline $\begin{array}{l}\text { Number of } \\
\text { focal lesion }\end{array}$ & $\bullet 1$ & 0.091 \\
\hline $\begin{array}{l}\text { HCC } \\
\text { location } \\
\text { (segment) }\end{array}$ & $\begin{array}{l}\text { S1/S2/S3/S4/S5/S } \\
6 / \mathrm{S} 7 / \mathrm{S} 8\end{array}$ & 0.969 \\
\hline $\begin{array}{l}\text { Number of } \\
\text { focal lesion }\end{array}$ & \multicolumn{1}{|c|}{ - 2} & 0.436 \\
\hline $\begin{array}{l}\text { Size of } \\
\text { focal lesion }\end{array}$ & $\begin{array}{l}\text { Range 2.2 (1.8 - } \\
\text { 4) }\end{array}$ & 0.421 \\
\hline
\end{tabular}

Data are expressed as Mean \pm Standard deviation OR number (\%) as appropriate. $n=$ number

Table 3: Comparison between Success and Recurrence of HCC focal lesions after RFA

\begin{tabular}{|l|l|l|l|}
\hline \multicolumn{1}{|c|}{ Variable } & $\begin{array}{l}\text { Success } \\
(\mathbf{n = 4 2})\end{array}$ & $\begin{array}{l}\text { Recurr } \\
\text { ence } \\
(\mathbf{n = 8})\end{array}$ & $\begin{array}{l}\mathbf{P} \text { - } \\
\text { value }\end{array}$ \\
\hline $\begin{array}{l}\text { Number of } \\
\text { focal lesion } \\
\bullet \quad \text { Single } \\
-\quad \text { Two }\end{array}$ & 37 & 8 & \\
\hline $\begin{array}{l}\text { Size } \\
\bullet \quad<3 \mathrm{~cm} \\
\bullet \quad \geq 3 \mathrm{~cm}\end{array}$ & 56 & 0 & $\mathbf{0 . 5 7 7}$ \\
\hline $\begin{array}{l}\text { Time operation } \\
\text { - } \leq 20 \mathrm{~min} \\
-\quad>20 \mathrm{~min}\end{array}$ & 6 & 8 & 0.000 \\
\hline \\
Data are expressed * by Chi-Square or
\end{tabular}

Fisher's Exact Test

Table 4: the Success and Recurrence of HCC focal lesions after MWA

\begin{tabular}{|l|l|l|l|}
\hline Variable & $\begin{array}{l}\text { Success } \\
(\mathbf{n = 4 8})\end{array}$ & $\begin{array}{l}\text { Recur } \\
\text { rence } \\
(\mathbf{n = 2})\end{array}$ & P-value \\
\hline $\begin{array}{l}\text { Number of } \\
\text { focal lesion } \\
\bullet \quad \text { Single } \\
\text { - Two }\end{array}$ & 46 & 2 & \\
\hline $\begin{array}{l}\text { Size } \\
\bullet \quad<3 \mathrm{~cm}\end{array}$ & 25 & 0 & $\mathbf{0 . 5 7 7}$ \\
$\bullet \quad \geq 3 \mathrm{~cm}$ & 23 & 0 & 0.000 \\
\hline
\end{tabular}

Data are expressed * By Chi-Square or Fisher's Exact Tests. 
Table 5: Difference between ablation success, recurrence, and ablation time in the microwave- and radiofrequency-ablated patients

\begin{tabular}{|l|c|c|c|}
\hline Variable & $\begin{array}{c}\text { RFA } \\
(\mathbf{n = 5 0})\end{array}$ & $\begin{array}{c}\text { MVA } \\
(\mathbf{n = 5 0})\end{array}$ & $\begin{array}{c}\text { P- } \\
\text { value }\end{array}$ \\
\hline $\begin{array}{l}\text { Number } \\
\text { of focal } \\
\text { lesions }\end{array}$ & 55 & 52 & 0.05 \\
\hline $\begin{array}{l}\text { Ablation } \\
\text { success }\end{array}$ & $\begin{array}{c}42 \\
(84 \%)\end{array}$ & $\begin{array}{c}48 \\
(96 \%)\end{array}$ & 0.000 \\
\hline $\begin{array}{l}\text { Ablation } \\
\text { recurrence }\end{array}$ & $\begin{array}{c}8 \\
(16 \%)\end{array}$ & $2(4 \%)$ & 0.000 \\
\hline $\begin{array}{l}\text { Ablation } \\
\text { time } \\
\text { (minute) }\end{array}$ & $\begin{array}{c}25 \\
(15-\end{array}$ & $\begin{array}{c}9(6- \\
15)\end{array}$ & 0.000 \\
\hline
\end{tabular}

Data are expressed as number (\%),* By ChiSquare or Fisher's Exact Tests.

Table 6: RFA Complication in (50) patients with HCC.

\begin{tabular}{|l|c|c|}
\hline Complication & N & \% \\
\hline $\begin{array}{l}\text { Post RFA } \\
\text { complications }\end{array}$ & 8 & 16 \\
\hline $\begin{array}{l}\text { Right side } \\
\text { pleural effusion }\end{array}$ & 4 & 8 \\
\hline $\begin{array}{l}\text { Sub-capsular } \\
\text { hematoma }\end{array}$ & 2 & 4 \\
\hline $\begin{array}{l}\text { Sub-cutaneous } \\
\text { hematoma }\end{array}$ & 2 & 4 \\
\hline
\end{tabular}

Data are expressed as number (\%) as appropriate $. n=$ number

Table 7: MVA complication in (50) patients with HCC.

\begin{tabular}{|l|c|c|}
\hline Complication & $\mathbf{N}$ & \% \\
\hline $\begin{array}{l}\text { Post MVA } \\
\text { complications }\end{array}$ & 2 & 4.0 \\
\hline $\begin{array}{l}\text { RT sided pleural } \\
\text { effusion }\end{array}$ & 0 & 0.0 \\
\hline $\begin{array}{l}\text { Subcapsular } \\
\text { hematoma }\end{array}$ & 0 & 0.0 \\
\hline $\begin{array}{l}\text { Subcutaneous } \\
\text { hematoma }\end{array}$ & 2 & 4.0 \\
\hline
\end{tabular}

Data are expressed number (\%) as appropriate. $n=$ number .
Table 8: Difference between RFA, MVA ablation complications

\begin{tabular}{|c|c|c|c|}
\hline Variable & $\begin{array}{c}\text { RFA } \\
(n=16)\end{array}$ & $\begin{array}{l}\text { MVA } \\
(n=4)\end{array}$ & $\begin{array}{c}\text { P- } \\
\text { value }\end{array}$ \\
\hline $\begin{array}{l}\text { RT sided } \\
\text { pleural } \\
\text { effusion }\end{array}$ & 4 & 0 & \multirow{4}{*}{0.05} \\
\hline $\begin{array}{l}\text { Subcapsular } \\
\text { hematoma }\end{array}$ & 2 & 0 & \\
\hline $\begin{array}{l}\text { Subcutaneou } \\
\text { s hematoma }\end{array}$ & 2 & 2 & \\
\hline $\begin{array}{l}\text { Post } \\
\text { operation } \\
\text { complication } \\
\text { s }\end{array}$ & 8 & 2 & \\
\hline
\end{tabular}

Data are expressed By Chi-Square or Fisher's Exact Tests.

Discussion

Hepatocellular carcinoma incidence is increasing because of increase in hepatitis $\mathrm{B}$ and $\mathrm{C}$ virus infection. The most common cause of HCC is cirrhosis and should undergo surveillance programs to early detection of tumors (Bruix and Sherman, 2011).

Several different loco-regional therapies for hepatic malignancy have been performed, including surgical resection, percutaneous ethanol injection, microwave ablation (MWA), radiofrequency ablation (RFA), high intensityfocus ultrasound, and trans-catheter arterial chemo-embolization (TACE).

This gives this study special importance and uniqueness, due to the presence of a large cohort's study with advanced liver disease that is in need of ablation of hepatocellular carcinoma not a candidate for surgery.

Firstly, our study showed that more than half of patients were males with a mean age of 48.1 \pm 10.4 years. This reported that HCC more common among males more than females. This is in line with (Abdel-wahab et al., 2007).

The cause of liver cirrhosis and HCC in our study was67\% of patients had HCV, $23 \%$ of patients had HBV, $6 \%$ of patients had both $\mathrm{HCV}$ and HBV while $4 \%$ of patients had unknown etiology for liver cirrhosis.

However, the cause of liver cirrhosis and HCC in their study was hepatitis $\mathrm{C}$ virus (HCV) infection in approximately $56.8 \%$ of the 
patients, while HBV infection approximately $2.7 \%$ of the patients (Saad et al., 2015). So, the prevalence of HCV in our study was higher than that in their study.

Evaluation of serum AFP in our study was only 8 patients had an elevation in serum AFP more than or equal to $400 \mathrm{ng} / \mathrm{ml}$ while more than half of patients had normal serum AFP.

Patients who are not fit for liver transplantation or resection are preferentially treated with percutaneous ablation which has less invasive options with low complication rates, and good outcomes in overall survival (McWilliams et al., 2010; Francica et al., 2007).

Comparisons of baseline characteristics data between both groups: There was no statistically significant difference as regard age, gender, and etiology of liver cirrhosis.

There was no significant difference between both groups as regard number, size, and site of the hepatic focal lesion. This there was no difference in any variable between both groups.

In our study Comparison evaluation for ablation success of patients who underwent radiofrequency ablation and patients who had recurrence after operation; a quarter of patients had local recurrences which developed in tumors more than $3.0 \mathrm{~cm}$ in diameter. There was no recurrence at the periphery and near the ablated tumor may be considered due to incomplete ablation of the HCC. There was no statistical difference in the age, sex, number of focal lesions, or segment of affected hepatic lobe distribution of patients who had complete ablation versus recurrence apart from the size of the focal lesion is the highly statistical significant ( $p$-value $=0.000$ ).

In this study, the most advantage of percutaneous RFA is the short hospital stay required after the treatment. If there is good selection of patients, per-cutaneous RFA may be done as an outpatient.

We can't determine the accurate area of coagulation after RFA. However, the easily defined margin of the cryoablation iceball is seen ultrasonographically.

The present study demonstrates, that both RFA and MWA techniques have the same mechanism depended on the generation of friction heat between the tissue and the electric current or the micro-wave.

Although in our study MVA showed less local recurrence and larger ablation area than for a similarly sized HCC treated by RFA $(98 \%$ MWA, $84 \%$ RFA; $P$ 0.00), the differences were statistically significant.

We compared between two groups according to complications. Complications developed in 8 patients (16\%) after RFA.

While MWA Related complications developed in 2 patients (4\%). Two patients had subcutaneous hematoma were noted. These two groups showed statistically significantly higher values as regard post-operative complications ( $\mathrm{p}$-value $=0.000$ ).

However, Lu et al. (2005) not agreed with our study which retrospectively compared 102 patients who were treated with microwave or $\mathrm{RF}$ ablation with no significant difference in survival or complication rates between the two groups.

The current study showed that lesions were more than $3 \mathrm{~cm}$ at high risk for local tumor progression after RFA. However, MWA showed a big area of ablation. This is in line with (Brace et al., 2007).

\section{Conclusions and recommendations:}

RFA and MWA are good ablative techniques. MWA showed more superiority than RFA in the overall outcome.

Conflict of interest: All Authors in the present study declared that there is no conflict of interest or financial support from any agency.

\section{References:}

Abdel-Wahab M, El-Ghawalby N, Mostafa M, Sultan A, El-Sadany M, Fathy O, Salah T, et al. (2007). Epidemiology of hepatocellular carcinoma in Lower Egypt, Mansoura Gastroenterology Center, 54(73):157-62.

Brace CL, Laeseke PF, Sampson LA, Frey TM, van der Weide DW, and Lee FT Jr. (2007). Microwave ablation with multiple simultaneously powered small-gauge triaxial antennas: results from an in vivo swine liver model. Radiology, 244(1):151156. 
Bruix J and Sherman M. (2011). American Association for the Study of Liver Diseases. Management of hepatocellular carcinoma: An update. Hepatology, 53(3) 1020-1022.

Fan S-T, Ng IOL, Poon RTP, Lo CM, Lu CL, Wong J. (1999). Hepatectomy for hepatocellular carcinoma. The surgeon's role in long-term survival. Arch Surg, 134(10):1124-1130.

Francica G, Pacella, Claudio Maurizio. (2007). Percutaneous laser ablation of small hepatocellular carcinoma. Current Med Imag Rev, 3(1): 61-65.

Francis Y. Yao, Ryutaro Hirose, Jeanne $M$. LaBerge, Davern TJ 3rd, Bass NM, Kerlan RK Jr, et al. (2005). A prospective study on downstaging of hepatocellular carcinoma prior to liver transplantation Downstaging hepatocellular carcinoma prior to liver transplantation. Liver Transpl, 11(12): 1466-1468.

Liu JH, Chen PW, Asch SM, Busuttil RW, Ko CY. (2004). Surgery for hepatocellular carcinoma: does it improve survival? Ann SurgOncol, 11(3): 298-303.

Lu MD, Xu HX, Xie XY, Yin XY, Chen JW, Kuang M, et al. (2005). Percutaneous microwave and radiofrequency ablation for hepatocellular carcinoma: a retrospective comparative study. J Gastroenterol, 40(11):1054-1060.

Luo BM, Wen YL, Yang HY, Hui Zhi, Xiao-Yun Xiao, Bing Ou, et al. (2005). Percutaneous ethano injection, radiofrequency and their combination in treatment of hepatocellular carcinoma. World J Gastroenterol, 11(40): 6277-6280.

Mazziotti A, Grazi GL, Cavallari A. (1998). Surgical treatment of hepatocellular carcinoma in cirrhosis: a Western experience. Hepato-Gastroenterology, 45(3):1281-1287.

McWilliams JP, Yamamoto S, Raman SS, Loh CT, Lee EW, Liu DM, et al. (2010). Percutaneous ablation of hepatocellular carcinoma: current status. J VascIntervRadiol, 21(8): 204-213.

Molla N, AlMenieir N, Simoneau E, Aljiffry M, Valenti D, Metrakos P, et al. (2014). The role of interventional radiology in the management of hepatocellular carcinoma. CurrOncol, 21(3): e480-e492.

Nagasue N. (1998). Liver resection for hepatocellular carcinoma: indications, techniques, complications, and prognostic factors. J HepatobilPancrSurg, 5(1): 7-13.

Saad Zaky, Nahed A. Makhlouf, Mohamed O. Abdel-Malek, Bakheet AA, Seif HM, Hamza HM, et al. (2015). Multidisciplinary decision making in the management of hepatocellular carcinoma: A hospital-based study. Turk J Gastroenterol 26(6): 498-505.

Solmi L, Nigro G, Roda E. (2006). Therapeutic effectiveness of echo guided percutaneous radiofrequency ablation therapy with a LeVeen needle electrode in hepatocellular carcinoma. World J Gastroenterol, 12(7):1098-2104.

Steven A. Curley, Francesco Izzo, Lee M. Ellis, J. Nicolas Vauthey, Paolo Vallone. (2000). Radiofrequency Ablation of Hepatocellular Cancer in 110 patients with Cirrhosis. ANNALS OF SURGERY, 232(3): 381-391.

Starzl TE. (2000). History of clinical transplantation.World J Surg, 24(7):759782. 